\title{
The hydrological role of biological topsoil crusts and water repellency in sandy dry-land areas
}

\author{
Aaron Yair ${ }^{1 *}$, Ram Almog ${ }^{2}$, Youval Arbel $^{3}$ \\ 'Department of Geography, Hebrew University of Jerusalem, Israel, * aaron.yair@mail.huji.ac.il \\ ${ }^{2}$ Ministry of Environmental Protection, Jerusalem, Israel \\ ${ }^{3}$ Zalul Environmental Association, Ramat Gan, Israel
}

\begin{abstract}
Dryland areas are regarded as highly sensitive to climatic changes. A positive relationship between rainfall and environmental factors is often assumed for areas with an average annual rainfall of 100-300 $\mathrm{mm}$. This assumption disregards the fact that a climate change in arid areas is not limited to climatic factors. It is often accompanied by a pronounced spatial variability in surface characteristics. The present work deals with the complex relationships among average annual rainfall, surface properties and the spatial redistribution of water resources in sandy areas located in the Northern Negev Desert. Two case studies are considered. The first deals with the hydrological effects of biological topsoil crusts on the water regime, along a rainfall gradient $(86-170 \mathrm{~mm})$. This study is based on five monitoring sites. Data obtained show a decrease in water availability with increasing annual rainfall. The findings are attributed to the decisive role played by the non-uniform properties of the topsoil crust along the rainfall gradient. The second case refers to the non-uniform development, and survival, of planted trees. Trees planted on steep dunes are well developed, with a high survival rate, whereas trees planted on low angle dunes are small. This study focused on the role of a water repellent layer on the water regime. Data obtained show a striking difference between steep and low dunes in all aspects studied, namely the degree of water repellency, frequency and magnitude of runoff events, infiltration depth and soil moisture. All variables monitored were found higher on steep than on low dunes. The large trees shed a substantial amount of leaves, whose decay developed a water repellent layer. Runoff generation over the repellent layer enhanced deep water penetration, through the process of subsurface flow. The lack of a water repellent layer over the low dunes prevented runoff generation, with its positive effects
\end{abstract}

Key words: sandy areas, rainfall gradient, water regime, biological soil crusts, water repellency, Negev Desert

\section{Introduction}

The relative textural homogeneity of sand particles, coupled with their high porosity and low water-holding capacity, have led to the widespread idea that water movement in unsaturated sand is fast and predominantly vertical, with no runoff generation. The said above is valid for the active sand ridges, where the mobile sand, poor in nutrients, with a low water holding capacity, allow fast water penetration preventing the establishment of biological topsoil crusts. This explanation is not valid for the lower parts of the dune slopes and for the interdune areas, where biological crusts are often observed (Fig. 1). Many studies conducted in a variety of sandy areas drew at- tention to the very important role that biological topsoil crusts play in the spatial redistribution of water resources (Bond, Harris 1964, Roberts, Carson 1971, Rietveld 1978, Brotherson et al. 1983, Yair 1990, Eldridge 1993, Kidron, Yair 1997, Eldridge et al. 2000, Warren 2001, Yair 2001, Kidron et al. 2003, Kidron 2015). Clogging of the pores, by the swelling of the microbial elements, leads to a reduced porosity and reduced infiltration (Avnimelech, Nevo 1964, Campbell 1979, Verrecchia et al. 1995). This process is further enhanced by the presence of fine-grained particles (Campbell 1979, Verrecchia et al. 1995, Wang et al. 2000). Under suitable rainfall conditions runoff is generated, resulting in the spatial redistribution of water resources and related ecological structure. 


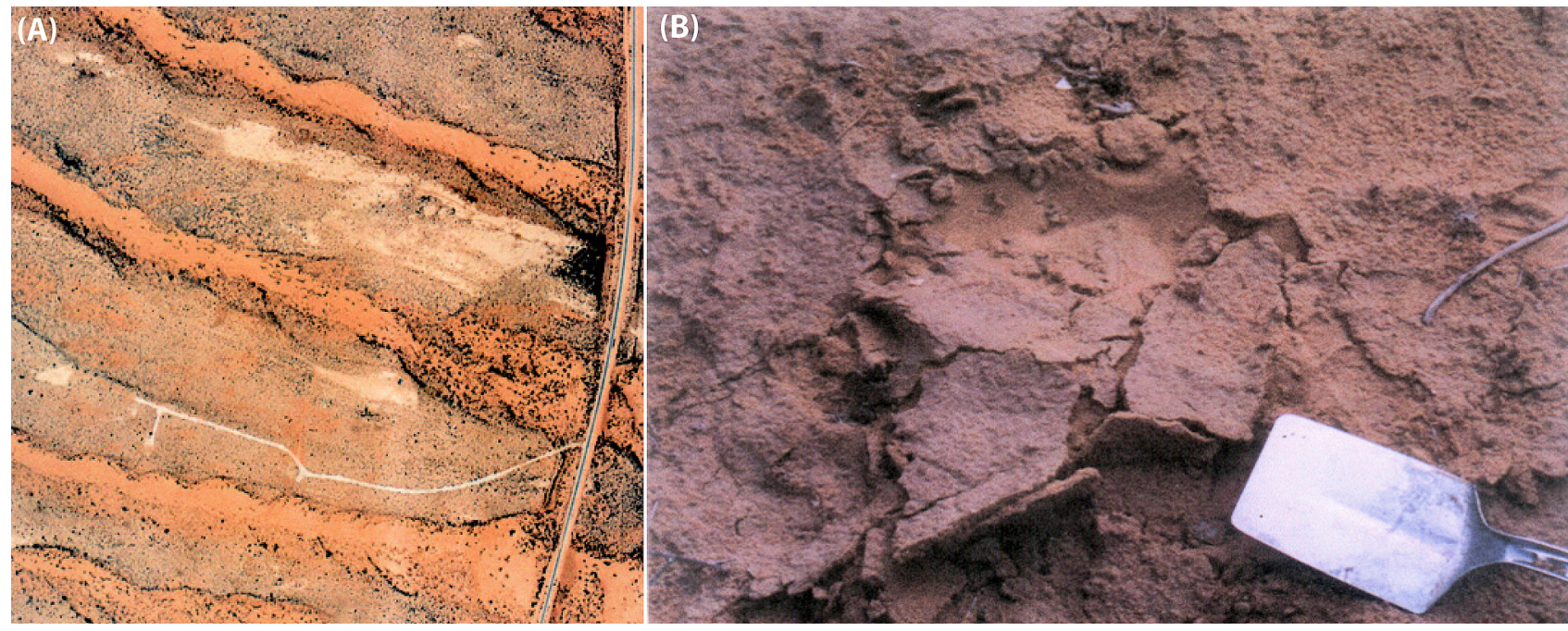

Fig. 1. General view of the dunes in the Negev Desert (A) and of the biological topsoil crust (B) (photo B: Almog, Yair 2007)

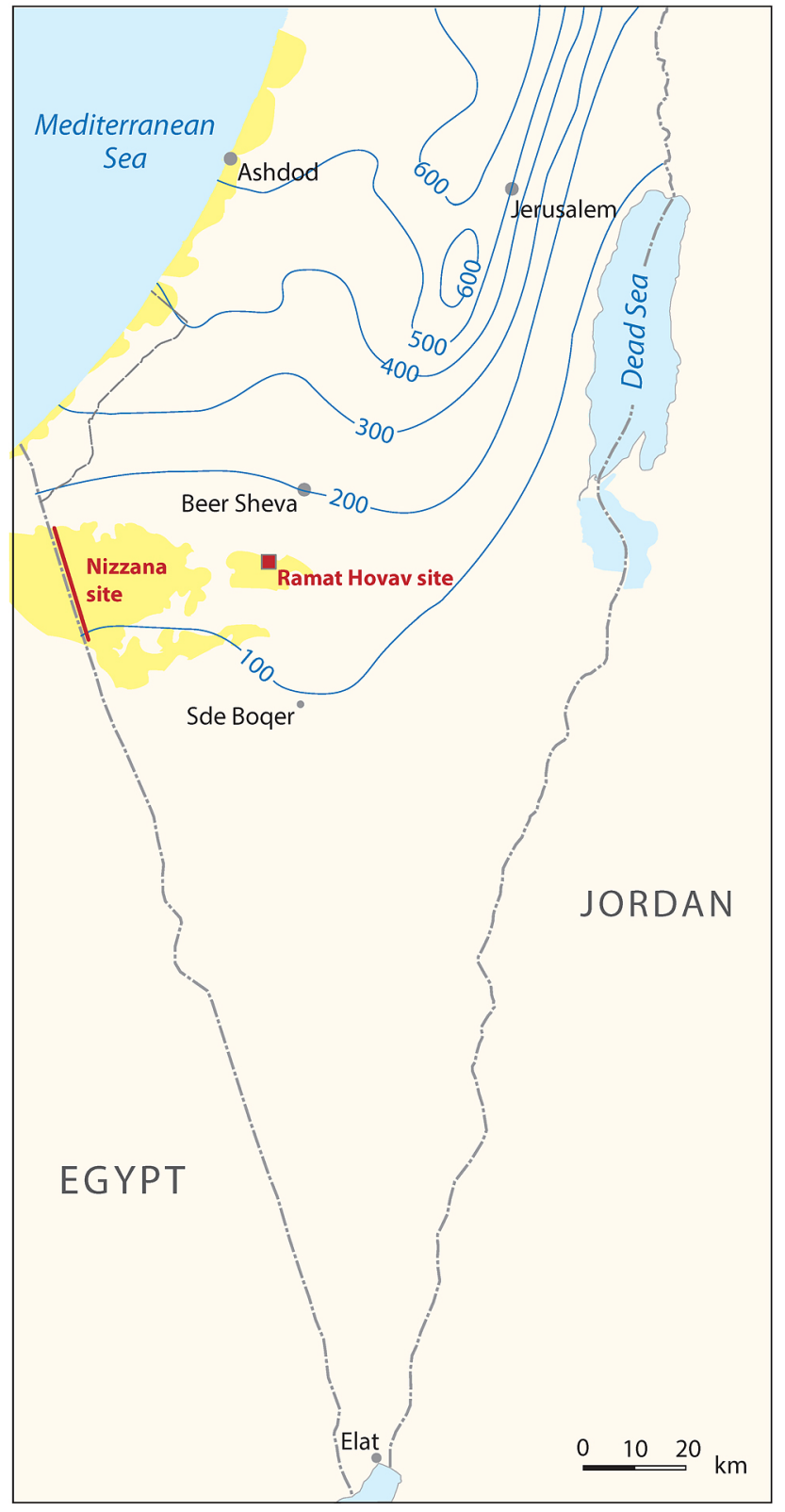

Other studies drew attention to the role of water repellent topsoil layers on the redistribution of water resources. Hydrophobicity is related to the coating of soil particles with an organic film that actually repels water (Robert, Carson 1971). Hydrophobicity has been attributed to polysaccharide secretions of algae and cyanobacteria. (Bond, Harris 1964, Savage et al. 1969, Rietveld 1978, Rutin 1983, Mashun, Farmer 1985, Jungerius, Dejong 1989, Dekker, Jungerius 1990, Mazor et al. 1996, Kidron, Yair 1997, Wessel 1998, Dekker et al. 1999, DeBano 2000, Doerr et al. 2000, Warren 2001, Arbel et al. 2005, Yang et al. 2014).

\section{Aim of study and description of monitoring sites}

The present study will focus on the complex relationships among the average annual rainfall, surface properties and the spatial variability of water resources in sandy areas located in the northern Negev Desert. The study area represents the eastern part of the extensive Sinai continental erg. Two research sites have been established in the area. The first site, Nizzana is located along the Israeli Egyptian border (Fig. 2). The work focused here on the role of biological topsoil crusts on runoff generation, and its effect on the water regime. The second site (Ramat Hovav), is located at the eastern part of the sandy area (Fig. 2). The work focused here on the role of water repellency on the development and survival of planted trees.

Fig. 2. Location of monitoring sites 


\section{Nizzana monitoring site}

The area is characterized by longitudinal dunes trending W-E, (Fig. 1) separated by 100-200 wide interdune corridors. The site extends over a distance of $35 \mathrm{~km}$ (Fig. 2). Average annual rainfall increases from $\sim 86 \mathrm{~mm}$ in the south to $\sim 170 \mathrm{~mm}$ in the north. The dunes are considered by Tsoar et al. (2008) as vegetated stabilized linear dunes. The prevalence of weak winds (Tsoar et al. 2008) explains many of the special and important properties of this sandy area, such as the high stability of very large areas, caused by the extensive development of biological topsoil crusts (Danin et al. 1989, Yair 1990), the relatively high content of fine-grained particles in the topsoil crusts (Verecchia et al. 1995), as well as the extensive vegetation cover (Allgaier 2008, Littmann, Berkowicz 2008, Tsoar et al. 2008). The work in this site focused on the role of biological topsoil crusts on runoff generation along the rainfall gradient.

Review of earlier studies conducted in the area

In order to obtain an initial insight into the issue of runoff generation in this area, a sprinkling experiment, with an intensity of $18.4 \mathrm{~mm} \mathrm{~h}^{-1}$, was conducted over a small plot covering $1.5 \mathrm{~m}^{2}$, located at the bottom of a north facing plot (Yair 1990). Runoff de-

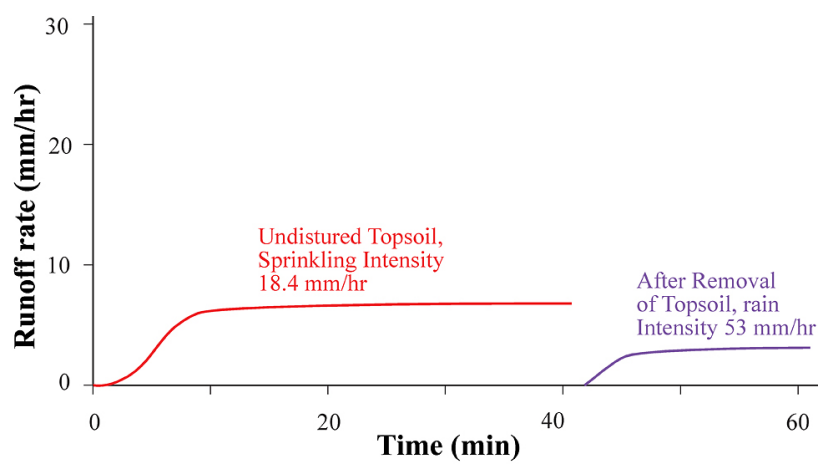

Fig. 3. Results of the sprinkling experiment

veloped within 3 minutes (Fig. 3). Final infiltration rate $\left(12 \mathrm{~mm} / \mathrm{hr}^{-1}\right)$ was reached within 12 minutes. An hour later a second sprinkling experiment was performed over the same plot, after the topsoil crust had been removed. Rain intensity in the second run was increased to $53 \mathrm{~mm} \mathrm{~h}^{-1}$. Despite the antecedent wet conditions, and the extremely high rain intensity applied, no runoff was observed for 42 minutes (Fig. 3). The results obtained clearly demonstrated the importance of the biological topsoil crust in limiting infiltration and enhancing runoff generation.

The sprinkling experiment was conducted at the southern part of the sandy area, where average annual rainfall is only $\sim 86 \mathrm{~mm}$. Field observations drew

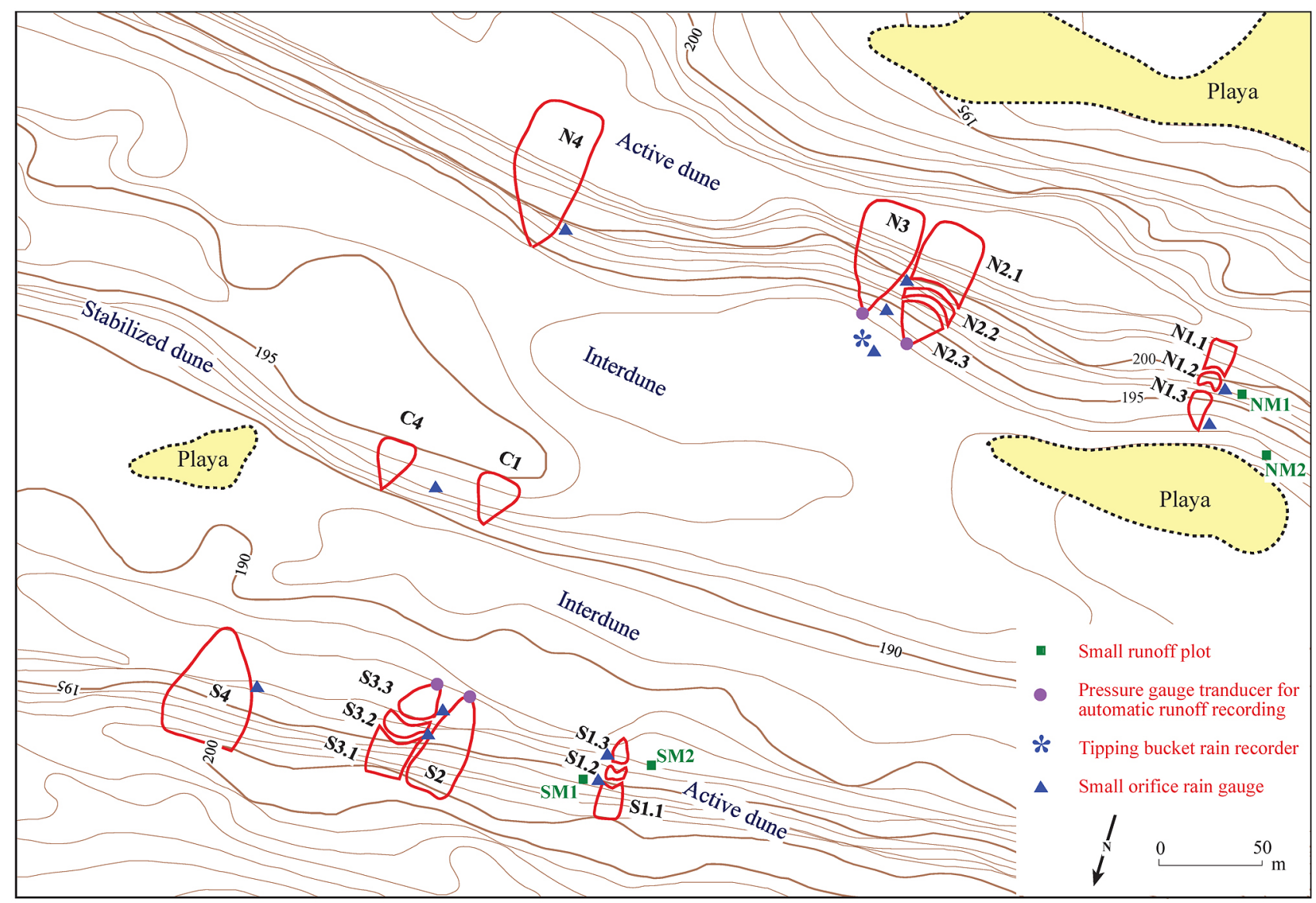

Fig. 4. Network of runoff plots in the Nizzana monitoring site 
attention to the spatial variability of the topsoil biological crusts over short distances, from the top to the base of a dune slope, as well as laterally. Following this observation, a network of runoff monitoring plots was established in the southern part of the sandy area (Fig. 4). Data obtained revealed significant differences in runoff generation over small distances, from the top to the bottom of a dune slope, as well as between the north and south facing slope (Kidron, Yair 1997). Similar differences have been reported by Eldridge (2001) who drew attention to the fact that marked differences in the crust type, even at small scales, revealed large differences in water flow through biological crusts.

\section{Aim of study}

The results of the previous works raised an important question regarding the relationships among average annual rainfall, crust properties, runoff generation and water availability for plants. Can we extrapolate data obtained to larger areas, with a different rainfall regime? Field observations, along the rainfall gradient (86-168 $\mathrm{mm}$ average annual rainfall), clearly show a differential development of the topsoil crust from south to north. The topsoil crust is thicker and darker in the northern than in the southern area, pointing to differences in crust properties (Almog, Yair 2007). In addition, the morphology of the dunes varies along the rainfall gradient from south to north, affecting the spatial extent of the biological topsoil crust. The topsoil crust is also far more developed in the northern than in the southern area. The field observations rose the following question: Are the differences in the properties of the biological crusts significant enough to exercise a strong differential effect on infiltration, runoff, soil moisture, and inhibit or even eliminate the expected positive effects with increasing average annual rainfall?

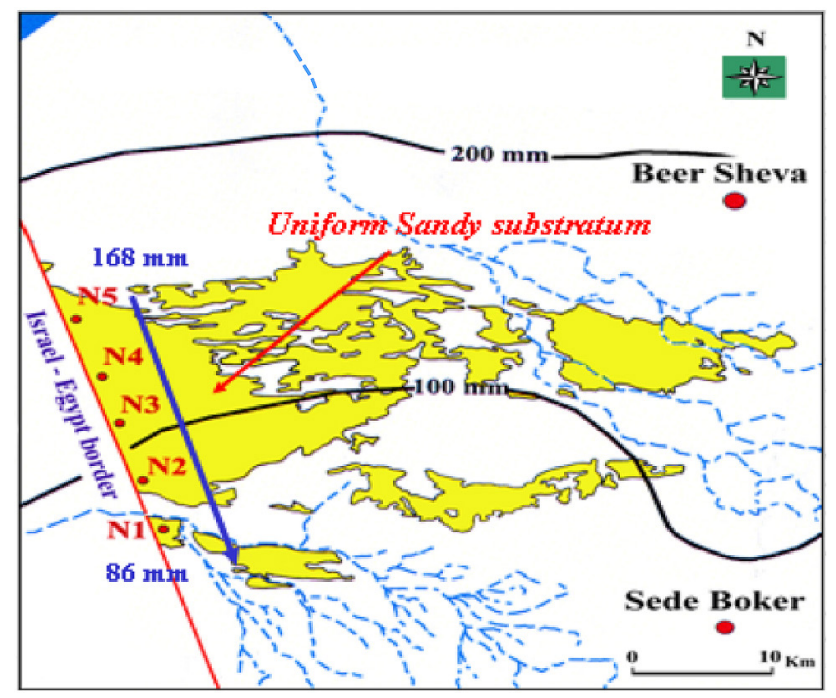

Fig. 5. Location of monitoring plots (Nizzana site) (Almog, Yair 2007)

\section{Methods}

In order to answer the questions listed above five monitoring sites, located at the lower flanks of north facing dune ridges, were established along the rainfall gradient (Fig. 5). Data collected covered the following variables: rainfall, runoff, soil moisture content, soil properties of the topsoil crusts: (crust thickness, particle size composition, water absorption capacity, organic matter content and electron scanning micrographs (ESM) of crust samples. Runoff plots had an area of $8 \mathrm{~m}^{2}$. Three of the plots (plots N1, N3 and N5) were equipped with a stage recorder and a rain recorder. In addition, a field survey of dead and alive perennial shrubs was conducted along three transects of $100 \times 1 \mathrm{~m}$ each, located at the dune base where, for topographical and hydrological reasons, the vegetation density is the highest. It was assumed that the survival and mortality of the perennial vegetation is a good indicator of long-term effects of water availability, along the rainfall gradient.

\section{Results}

Rainfall and runoff data cover the rainfall years 2001-2003. Runoff volumes collected in both years, decreased with increasing annual rainfall (Table 1).

Table 1. Rainfall-runoff relationships (2001-2003)

\begin{tabular}{|c|c|c|c|}
\hline \multirow{2}{*}{$\begin{array}{c}\text { Rainfall } \\
\text { year }\end{array}$} & \multirow{2}{*}{ Plot } & Annual rainfall & Annual Runoff \\
\hline & & \multicolumn{2}{|c|}{$(\mathrm{mm})$} \\
\hline \multirow{3}{*}{$2001-2002$} & N5 & 146.5 & 0.55 \\
\hline & N3 & 76.2 & 0.93 \\
\hline & N1 & 57.7 & 1.80 \\
\hline \multirow[t]{3}{*}{ 2002-2003 } & N5 & 82.7 & 0.12 \\
\hline & N3 & 95.1 & 1.06 \\
\hline & N1 & 99.3 & 3.60 \\
\hline
\end{tabular}

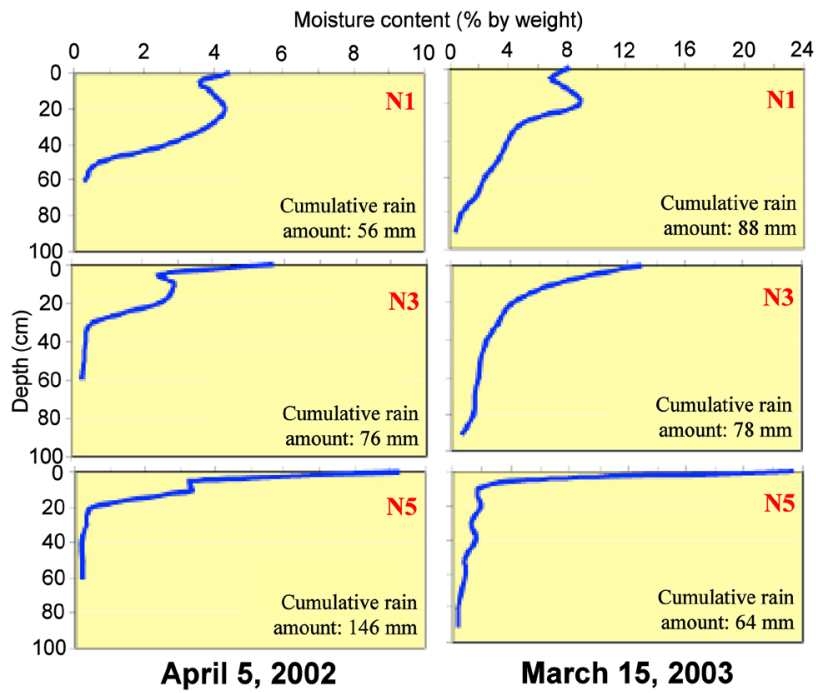

Fig. 6. The course of soil moisture with depth (Almog, Yair 2007) 
A
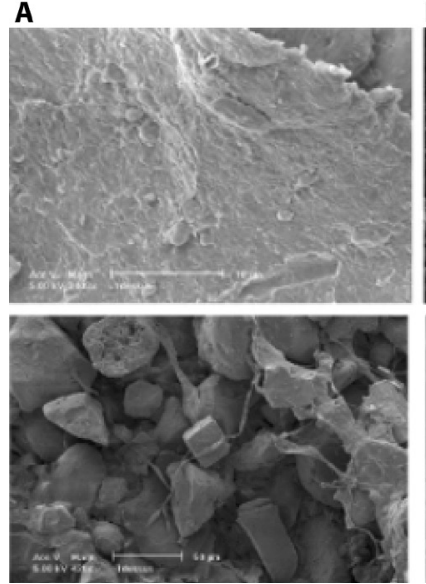

Fig. 7. Electron scanning micrograph photos of the biological crusts (Almog, Yair 2007)

Soil moisture depth decreased with increasing annual rainfall (Fig. 6). An additional interesting fact is that water absorption by the upper part of the biological crust is always highest at plot N5 and decreases southwards along the rainfall gradient. Table 2 presents the properties of the topsoil crusts along the rainfall gradient. There is a clear increase in all variables considered from south to north.

Figure 7 shows the ESM (electronic scanning microscope) figures of the biological crust in the southern and northern areas (plots N1 and N5). The biological crust at N1 is composed of a very thin microbial film, while in the northern area the crust is very rich in large mosses (Fig. 8), known for their

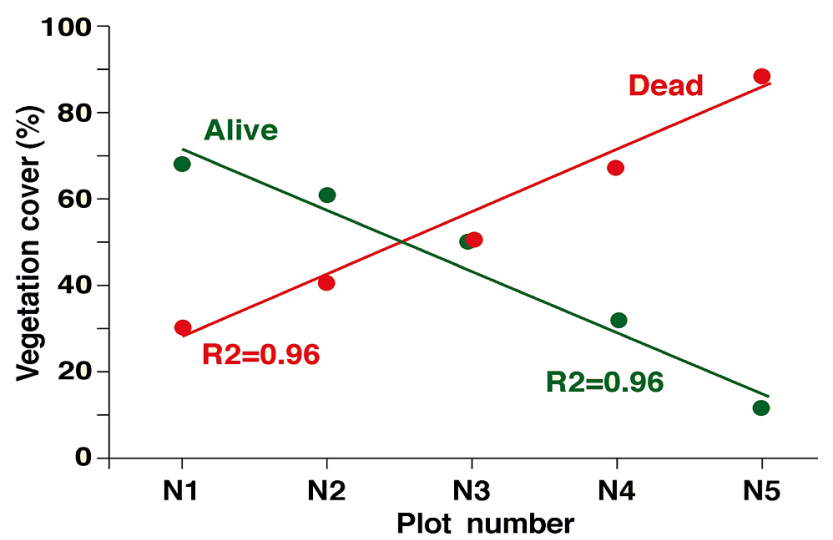

Fig. 9. Percent of alive and dead shrubs along the rainfall gradient

high-water absorption capacity. Finally, Figure 9, clearly shows a linear increase in the percentage of dead plants with increasing average annual rainfall. An opposite trend is observed for the alive perennial shrubs. Such a pattern is a good indicator of the longterm effects on water availability along the rainfall gradient. Water availability decrease with increasing annual rainfall.

\section{Discussion}

Runoff data obtained (Table 1) may indicate two opposing processes. The first is an increase in infiltration with increasing annual rainfall. The second is that significant differences in the composition and properties of the topsoil crust, limit the depth of
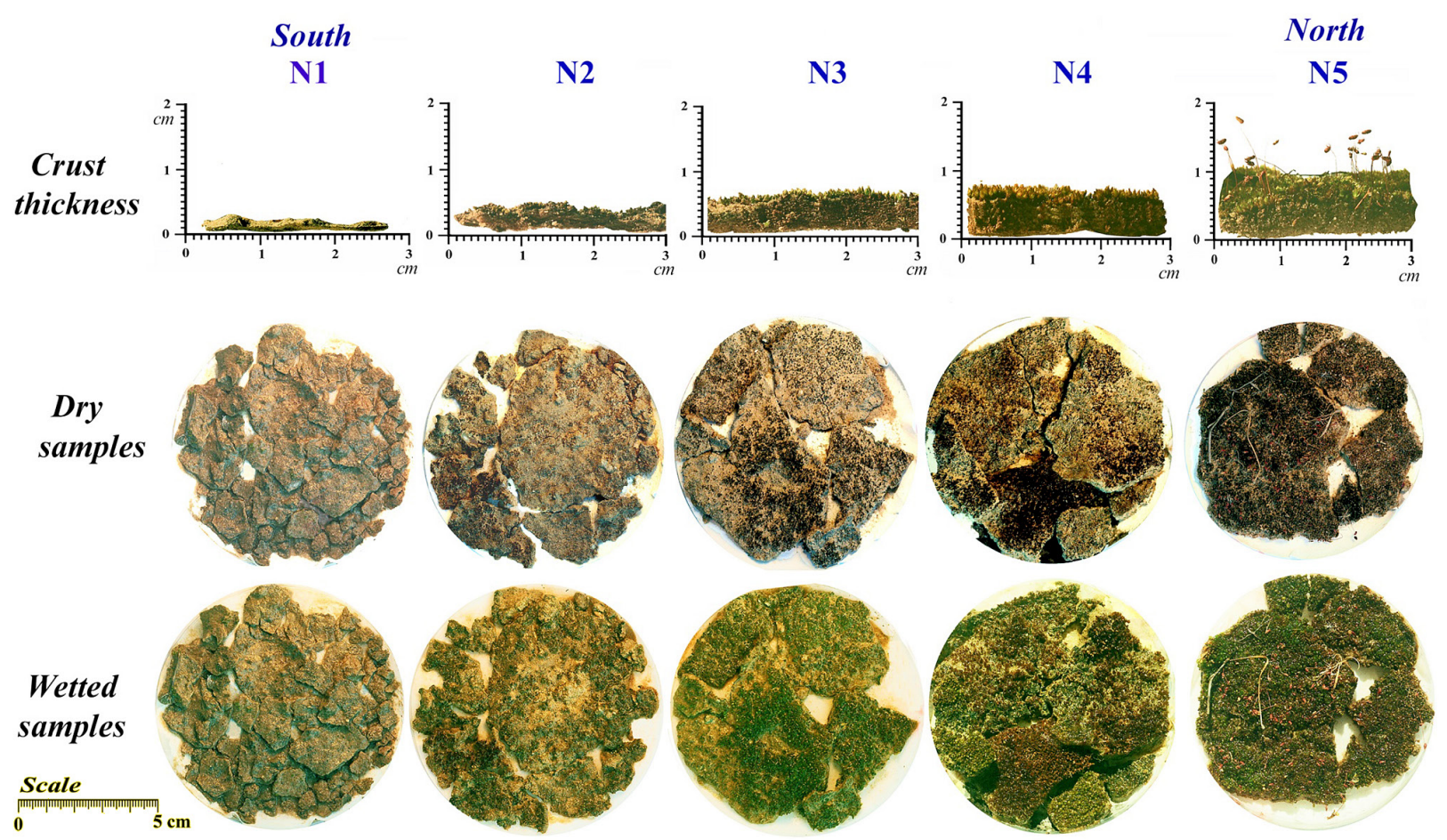

Fig. 8. Topsoil crust thickness without (dry samples) and with mosses (wetted samples) along the rainfall gradient (Yair et al. 2011) 
Table 2. Properties of topsoil crusts along the rainfall gradient $(n=20)$ (Almog, Yair 2007)

\begin{tabular}{ccccc}
\hline Location & Silt and clay $(20 \%)$ & Crust thickness $(\mathrm{mm})$ & Organic matter content $(20 \%)$ & Field capacity (\% by weight) \\
\hline N1 & 26.7 & 5.3 & 2.7 & 6.1 \\
N3 & 37.8 & 7.1 & 4.2 & 11.9 \\
N5 & 49.2 & 11.2 & 7.6 & 19.5 \\
\hline
\end{tabular}

rainwater penetration, due to their high-water absorption capacity. Data obtained support the second hypothesis. In both years, depth of water penetration was higher in the drier than in the wetter area (Fig. 6). Data obtained are ascribed to substantial differences in the properties of the topsoil crusts along the rainfall gradient (Table 2). Organic matter content, percent of silt and clay, crust thickness and field capacity increase with increasing annual rainfall. Such trends explain the significant increase in water absorption capacity of the topsoil crust with increasing annual rainfall. An additional factor that contributes to the increase in water absorption capacity with increasing annual rainfall is the composition of the biological crusts. The biological crust in the drier area is mainly composed of a thin and smooth microbial crust (Fig. 7A). This crust absorbs a limited amount of water, seals quickly and generates runoff frequently. The northern crust is predominantly composed of mosses (Fig. 7B), known for their high water- absorption capacity. Such crusts act as a sponge. The limited depth of rainwater penetration in the northern area explains the higher mortality of the perennial shrubs with increasing annual rainfall.

\section{Conclusions}

Data presented cast doubt on the prevailing idea that an increase in average annual rainfall has always a positive effect on the ecosystem. Such an approach disregards the important role played by the non-climatic factors, namely surface properties, on the water regime and its influence on water availability. The lower survival of the perennial plants in the wetter area may be regarded as a desertification phenomenon, related to the increase in water absorption by the topsoil biological crust with increasing average rainfall. In addition, most climatic models refer to extensive areas. They disregard the spatial variability of surface properties, which is very common in drylands areas. Finally, the expected rainfall decrease in dryland areas may have positive effects in some sandy dryland areas, characterized by the extensive occurrence of biological topsoil crusts. A decrease in annual rainfall in the study area would be expected to have positive effects by limiting the extent of the areas covered by mosses, characterized by a high-water absorption capacity.

\section{Ramat Hovav Site}

Afforestation in arid sandy areas is a widespread practice as a measure to prevent sand encroachment on cultivated land, railways and roads. Vegetation growth, and litter accumulation on the dune surface, reduce the rate of sand transport, enhance the deposition of fines, improve the nutrition balance through the decay of the organic litter and improve soil structure and the water holding capacity of the soil (Stevens 1974, Burley 1990). The Tamarix aphylla trees are known for their adaptation to arid conditions and mobile sand (Waisel 1960, Misak, Draz 1997). Tamarix aphylla develops quickly its root system and sheds continuously its twigs, resulting in the fast formation of a litter layer. These trees can survive and develop in an area where average annual rainfall is 100-150 $\mathrm{mm}$ (Waisel 1960, Stevens 1974). Survival rates of $90 \%$ have been reported five years after tree plantation (Misak, Draz 1997).

In order to stop the sand drift in the northern Negev Desert, afforestation of the sandy area took place from 1950 to 1970 . Average annual rainfall is $150 \mathrm{~mm}$ with a high annual variability in the range of $60-250 \mathrm{~mm}$. The rainy season is limited to the winter months from October to May. Potential annual evaporation is $2300 \mathrm{~mm}$. Tamarix aphylla trees were planted on the sand dunes, at distances of $2 \mathrm{~m}$, at the end

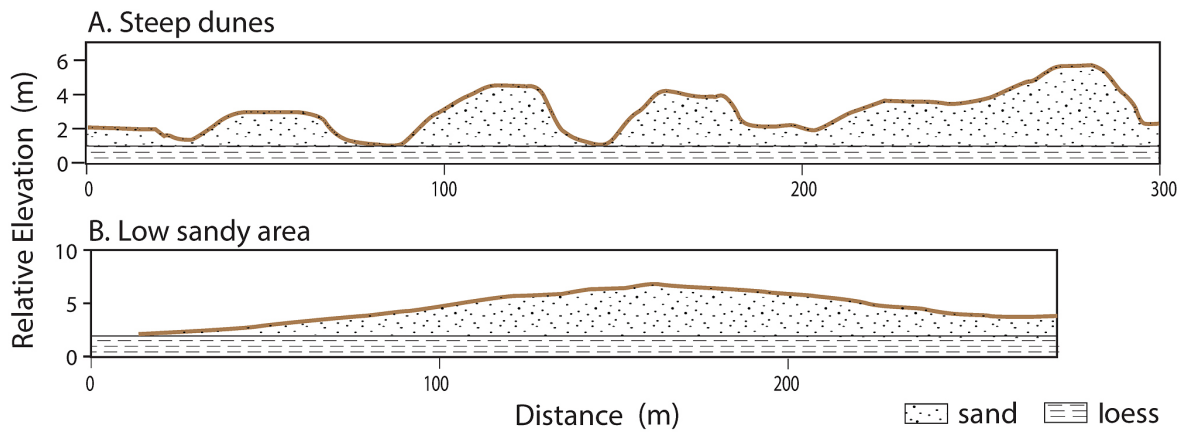

Fig. 10. Topography and lithology of the dunes at Ramat Hovav 

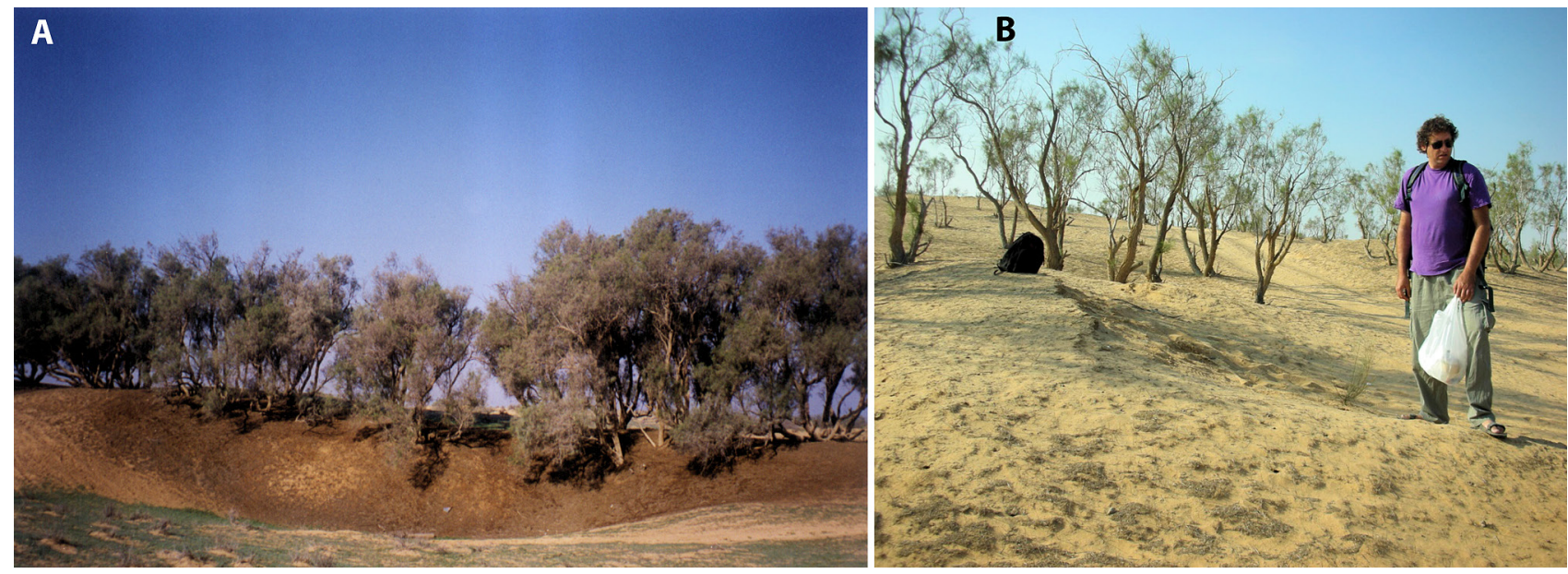

Fig. 11. View of the well-developed and small trees on dunes with different inclination

of the rainy seasons, when wetting depth exceeded $80 \mathrm{~cm}$. The planted area is characterized by two different dune types: high dunes with steep slopes, and low angle dune (Fig. 10). Field observations 45 years after planting show a non-uniform survival and development of planted trees. Trees planted on the top of the steep dunes show a high survival rate and are well developed with large canopies (Fig. 11A), whereas trees planted on the relatively low angle sandy areas show very poor development (Fig. 11B). They are small and shrivelled, with a low survival rate. In addition, a striking difference is observed below the canopy. The surface below the well-developed trees is covered by a litter layer, up to $5 \mathrm{~cm}$ thick, underlain by a sand layer rich in decomposed organic material. The thickness of the two layers decreases downslope. Both the litter layer and the decomposed organic layer are missing in the area with the low dunes.

The understanding of the systematic non-uniform developed trees, over short distances, needs to deal with two questions. The first: why is it that the initial development of trees planted on top of the steep dunes was better than on the gentle slopes. Previous studies by McCord and Stephens (1987), Berndtsson et al. (1996) and Yair et al. (1997) have shown a downslope increase in water content on steep dunes. The process is attributed to subsurface flow from the top to the base of the dunes. Such a process is expected to be more predominant on steep than on gentle slopes, explaining thus the critical difference in the initial water regime between steep and gentle dunes. The second question relates to the role of the organic sandy layer on the water regime. Water repellent soils have been often described in sandy soils, in various environments (Bond, Harris 1964, Krammes, DeBano 1965, Savage et al. 1969, Mashum, Farmer 1985, Jungerius, Dejong 1989, Dekker et al. 1999, Doerr et al. 2000, Yang et al. 2014.). If the organic layer in the study area is hydrophobic, it would be expected to enhance runoff generation, reduce infiltration, preventing the good development of the trees at the top of the dune. Alternatively, runoff originated over the hydrophobic layer infiltrates at the dune base, where it is available for the trees. The additional possibility is that due to unstable wetting fronts, predominant flow lines develop in the area, allowing deep infiltration. Several authors have described the occurrence of finger flows in water repellent soils (Imeson et al. 1992, Hendricks et al. 1993, Ritsema, Dekker 1994, 1997, Bauters et al. 1998). Water concentration by finger flows is held responsible for a fast movement of infiltration water to a great depth, creating a local water concentration, at a depth beyond that allowed by direct rainfall.

\section{Aim of study}

The aim of the present work is to explain the spatial non-uniform development, and survival, of planted trees through an understanding of the factors affecting the local water regime on steep and gentle dunes.

\section{Methods}

Two adjacent sites, $150 \mathrm{~m}$ apart, were chosen for the study. One of them represents a steep dune, and the second a gentle dune. The study covered the following aspects:

1. Determination of the degree of water repellency, on the basis of the water drop penetration time method (WDPT), as described by Krammes and DeBano (1965). This method measures the time required for a droplet to infiltrate into the soil. According to Dekker and Ritsema (1994) if the time required for infiltration into the soil exceeds 5 seconds, the surface is water repellent. Doerr (1998) describes soils as hydrophobic if infiltration time is at least one minute. The hydrophobicity tests were conducted before the rainy season, under dry surface conditions. Due to the expected spatial variability of water repellency drops of distilled water were placed at 5-7 different locations within each plot. 
Table 3. Properties of runoff plots in the Ramat Hovav site

\begin{tabular}{|c|c|c|c|c|c|}
\hline \multirow{2}{*}{ Plot number } & \multirow{2}{*}{$\mathrm{WDPT}^{*}[\mathrm{~s}]$} & Litter Cover & Slope & \multirow{2}{*}{ Area $\left[\mathrm{m}^{2}\right]$} & \multirow{2}{*}{ Canopy cover $[-]$} \\
\hline & & \multicolumn{2}{|c|}{$[\%]$} & & \\
\hline A1 & $60-300$ & 75 & $15-35$ & 15 & Partial \\
\hline A2 & $300-600$ & 85 & 30 & 5 & Low \\
\hline A3 & $45-120$ & 25 & 40 & 5 & None \\
\hline A4 & $120-300$ & 95 & 7 & 5 & Complete \\
\hline A5 & $60-300$ & 85 & 30 & 5 & Partial \\
\hline B1 & 0-10 & 8 & $10-15$ & 15 & Partial \\
\hline B2 & $5-30$ & 12 & 12 & 5 & Partial \\
\hline B3 & $0-25$ & 3 & 13 & 5 & None \\
\hline
\end{tabular}

*WDPT - water drop penetration time

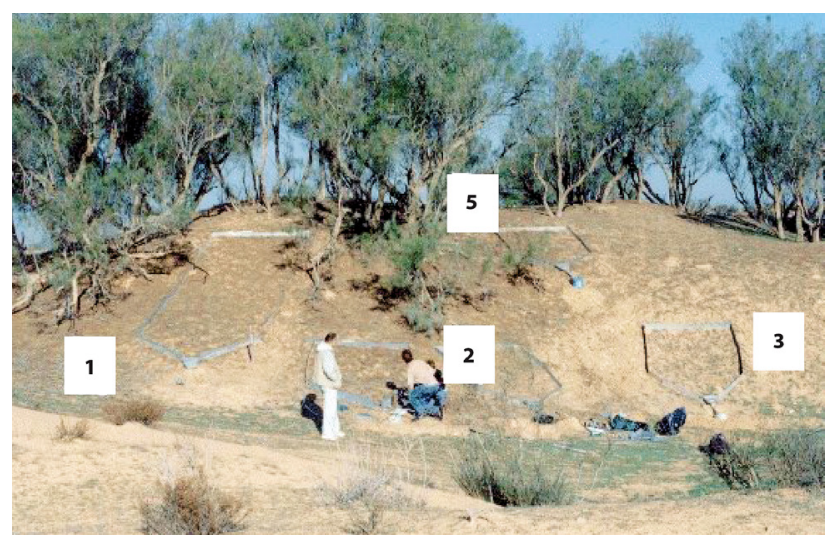

Fig. 12. View of runoff plots A1, A2, A3 and A5 (Ramat Hovav site)

2. The monitoring of rainfall-runoff relationships, under natural rainfall conditions, was based on runoff plots. Storm rain amounts were obtained by small orifice rain gauges placed in the vicinity of the plots. Five runoff plots (plots A1-A5) were established on the flanks of a steep dune (Fig. 12). The litter layer and the underlying hydrophobic sandy layer are thick and contiguous. Three runoff plots (plots B1-B3) were established on the gentle slope. The litter cover is very sparse, and very thin. The properties of the plots are given in Table 3.

3. The local topography and lithology (Fig. 10) has been obtained by a soil auger.

4. Moisture profile, from the top to the base of the dunes, down to a depth of 2.5 was measured, at both sites, during the winter season. Samples for moisture analysis were taken every $40 \mathrm{~cm}$ with a soil auger.

Results

Data on water repellency are given in Table 3. A common feature, observed in all plots, is a high variability in WDPT values over distances of tens of centimetres. However, data obtained show a pronounced difference between plots on the steep dune (A1-A5), and plots on the low dune (B1-B3). WDPT values for
Table 4. Rainfall-Runoff Relationships (1998-1999)

\begin{tabular}{cccccccc}
\hline Date & $19 / 12$ & $5 / 1$ & $11 / 1$ & $28 / 1$ & $12 / 2$ & $20 / 2$ & $2 / 3$ \\
\hline$[\mathrm{mm}]$ & 11.0 & 15.0 & 11.1 & 7.5 & 16.0 & 10.0 & 9.0 \\
\hline Plot & \multicolumn{7}{c}{ Runoff Coefficients (\%) } \\
\hline A1 & 0.10 & 3.70 & - & 0.00 & 0.01 & 0.02 & 0.30 \\
A2 & 6.80 & 5.70 & 1.10 & 0.70 & 0.52 & - & 0.55 \\
A3 & 0.65 & 8.20 & 0.80 & 0.20 & 0.18 & 0.00 & 0.33 \\
A4 & - & 0.00 & - & 0.00 & 0.00 & 0.50 & 0.00 \\
A5 & 0.00 & 1.50 & - & 0.06 & 0.29 & - & 0.20 \\
B1 & - & 0.00 & - & 0.00 & 0.00 & - & - \\
B2 & - & 1.10 & - & 0.00 & 0.65 & - & - \\
B3 & - & 0.80 & - & 0.00 & 0.10 & & \\
\hline
\end{tabular}

plots B vary in the small range of $0-30 \mathrm{~s}$. They are associated with a low litter cover (3-12\%), and extensive areas with bare surface. WDP values for plots A are much higher being in the range of 45-600 seconds. In one plot (plot A2) water repellency lasted for 20 minutes. The high values are associated with a high litter cover (25-95\%, Table 3).

The monitoring of rainfall-runoff relationships was conducted during the rainfall year 1997-1998 (Table 4). Annual rain amount was $105 \mathrm{~mm}$, below the longterm average. Half of the storms had rain amounts below $5 \mathrm{~mm}$. Runoff developed only in storms with an intensity higher than $15 \mathrm{~mm} \mathrm{hr}^{-1}$ for at least five minutes. Data obtained are not complete, as some of the plots were damaged by repeated vandalism. Despite this mishap several trends can be discerned:

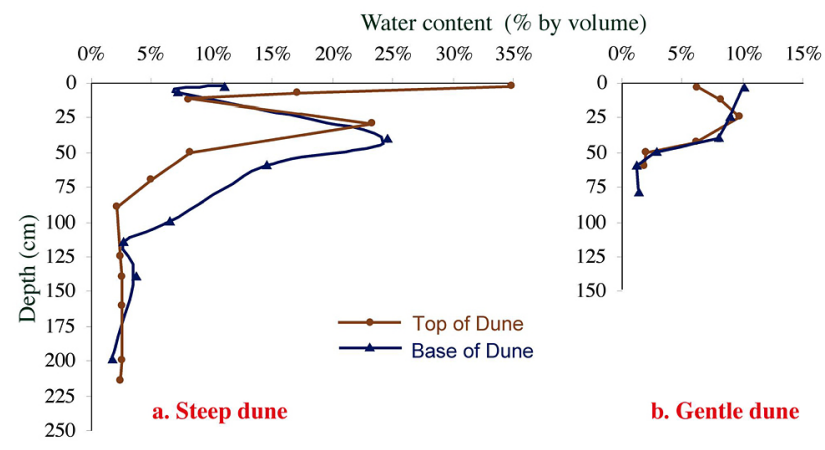

Fig. 13. Soil moisture profile after a storm of $30 \mathrm{~mm}$ 


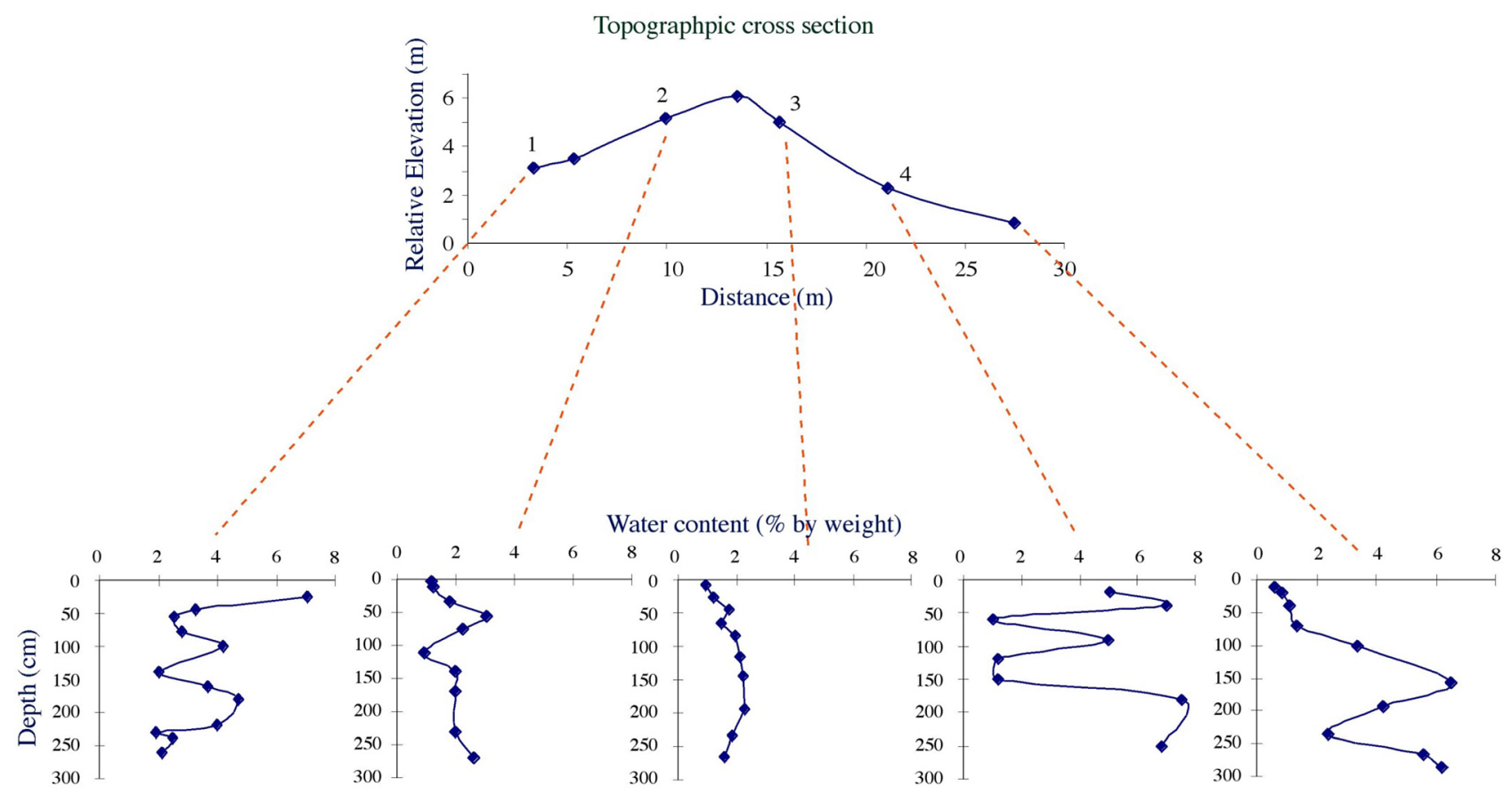

Fig. 14. Moisture profiles at the end of the rainy season along the cross section of the dune

Runoff frequency and runoff magnitude are higher on plots A than on plots B. Runoff coefficient decrease with time during the wet season, parallel to the increase in soil moisture. This trend is especially noticeable in plots $\mathrm{A} 2$ and $\mathrm{A} 3$, the most responsive plots to rainfall. This result is consistent with previous works (Witter et al. 1991, Burcar et al. 1994, Doerr et al. 2000), which indicate a decrease in water repellency with increasing wetness.

Figure 13 displays the soil moisture regime along a steep and a gentle slope following a storm of 30 $\mathrm{mm}$. Depth of water penetration at the low angle dune is limited to $50 \mathrm{~cm}$, and the highest water content is $10 \%$, at a depth of $25 \mathrm{~cm}$. In the case of the steep dune depth of water penetration is $\sim 100 \mathrm{~cm}$, and moisture content at a depth of $50 \mathrm{~cm}$ is quite high $25 \%$. The most striking difference is observed at the base of the steep dune where the depth of water infiltration reached $150 \mathrm{~cm}$. Figure 14 displays the moisture profiles at the end of the rainy season over the steep dune. Accumulated rain amount was quite low $(105 \mathrm{~mm})$. Taking into consideration the field capacity of the sand (about 10\%), and assuming no evaporation losses, the depth of water percolation should not exceed $\sim 100 \mathrm{~cm}$. However, the depth of infiltrated waters exceeded this value, with two or three distinct layers with high water content identified.

\section{Discussion}

The discussion will focus on three aspects. The first relates to the initial conditions prevailing over steep and low dunes. The second relates to the positive ef- fect of the water repellent layer on the water regime, and the last on the role of the stratigraphic section.

The differences in the initial pattern of water content over a steep and a low dune are illustrated in Figure 10. The moisture profiles represent the response of the two types of dunes to the first significant storm of the rainy season amounting to $30 \mathrm{~mm}$. Data obtained clearly show deeper water penetration, and higher water content, over the steep dune. The deeper infiltration over the steep dune was obtained, even though less water reaches the ground, due to rainwater interception by the extensive canopy cover, and the high-water absorption of the thick litter layer. The most significant feature is that water content, at the end of the rainy season, was higher at the base of the dune than at its upper part (Fig. 14). The downslope increase in water content is attributed to a process of subsurface flow from the top to the base of the dune. Such a process has been reported in studies conducted in China (Berndtsson et al. 1996), New Mexico (Stephen et al. 1986, McCord, Stephens 1987), and in Israel (Yair et al. 1997). The occurrence of subsurface flow is supported by the root pattern of the trees. A trench dug along the flank of a steep dune shows a high concentration of roots, along the flank of the dune at a depth of 40-60 $\mathrm{cm}$, and a second concentration of roots at a depth of $150-200 \mathrm{~cm}$. The identification of two to three beds with high water content (Fig. 14) is explained by differences in the compaction of sand beds within the dune, coupled with slight differences in the particle size compositions. The process of subsurface flow, and water concentration, is missing in the low dunes. 
In addition, the fact that in the low dunes the loess layer occurs at a very shallow depth (sometimes even at the surface) plays an important role in the local water regime. This layer, rich in fine grained particles (up to $\sim 28 \%$ silt and clay), absorbs all rainwater at most storms, limiting the depth of water penetration. Infiltrated waters are lost afterwards by evaporation, between two consecutive rainstorms. Evaporation losses are minimized over the steep dunes, due to rapid deep-water infiltration.

\section{Conclusions}

The differential development of the planted trees is attributed to two mechanisms. The chain of events described above shows that a positive feedback occurs on steep dunes. Due to their high slope angle, a process of lateral subsurface flow, towards the base of the dune occur. In view of the low capillary movement in the sandy substratum, the deeply infiltrated waters are subtracted from evaporation, leading to the creation of a locally improved water regime. The Tamarix aphilla trees, known for their very rapid development of the root system, grow quickly and shed a substantial amount of leaves. The decay of the leaves results in the formation of a water repellent layer, where the frequency of runoff generation is high. Flow discontinuities, coupled with the phenomenon of finger flows, further increase the initial process of water concentration, and deep-water penetration (down to $3 \mathrm{~m}$ ), in a relatively dry rainy year (only $105 \mathrm{~mm}$ ).

\section{General conclusion}

Climatologists use aridity indices to express the relationship between climatic variables (average annual rainfall, evaporation, radiation) and the environment. These variables tend to imply that the acuteness of aridity depends upon prevailing atmospheric conditions, principally precipitation, and that aridity is inversely correlated to annual precipitation. This approach is certainly correct for annual crops, where yields are greatly influenced by the annual precipitation, and the temporal distribution of rainfall during the rainy season. But it does not appear to fit the relationship between climate and environment at a desert fringe, if regional scales and longer time scales are considered. Surface controls, such as the extent of biological topsoil crusts, slope angle, soil particle size distribution, and water repellent surfaces will influence the degree to which water can be concentrated into a smaller area, making such an area potentially more fertile. The complex, and even contrasting relationships, between average annual rainfall in some sandy areas are very well displayed in the case of the Nizzana study area. A decrease in annual rainfall would, possibly, be expected to have a positive effect in the wetter area, by limiting the extent of the area covered by mosses, that limit infiltration depth. The opposite effect may be expected in the drier area, through a reduction of the area covered by cyanobacteria and fungi. Results obtained may not be applicable to sandy areas with strong winds that prevent the development of biological topsoil crusts. An extreme case of the negative effect of rainfall increase at a desert fringe has been reported by Yair (1983, 1994). Loess deposition on top of rocky surfaces, in the Upper Pleistocene, resulted in a desertification effect, caused by a substantial increase in rainwater absorption at a shallow depth, by the loess material rich in fine-grained particles. Infiltrated waters are lost afterwards by evaporation, resulting in the development of saline soils. a saline soil.

Data presented clearly show that average annual rainfall is not a good indicator of water resources in dryland areas. We believe that a better understanding of the factors that determine aridity provide a better basis for defining the degree of aridity, under changing climatic conditions, and on the whole a superior mean for combating desertification and determining the agricultural potential of some arid zones.

\section{Acknowledgments}

The study in the Nizzana area was supported by the Arid Ecosystem Research Center of the Hebrew University of Jerusalem. Warm thanks are due to Mr. E. Sachs for his help in the field work, and data processing. The study on the afforestation was supported by the Israeli Forestry Organization. Thanks are due to Mrs. M. Kidron of the Department of Geography, Hebrew University of Jerusalem, for drawing the illustrations.

\section{Authors' contributions}

Aaron Yair: 60\%, Ram Almog: 20\%, Youval Arbel: $20 \%$.

\section{References}

Allgaier A., 2008. Aeolian sand transport and vegetation cover. In: S.W. Breckle, A. Yair, M. Veste (eds), Arid Dune Ecosystems. Ecological Studies 200: 211-223.

Almog R., Yair A., 2007. Negative and positive effects of topsoil biological crusts on water availability along a rainfall gradient in a sandy arid area. Catena 70: 437-442.

Arbel Y., Yair A., Oz S., 2005. Effects of topography and a water repellent layer on the nob-uniform development of planted trees in sandy arid area. Journal of Arid Environments 60: 67-81.

Avnimelech Y, Nevo Z., 1964. Biological clogging of sands. Soil Science 98: 222-226.

Bauters T.W.J., Dicarlo D.A., Steenhuis T.S., Parlange J.Y., 1998. Preferential flow in water sands. Soil Science Society American Journal 62: 1185-1190.

Belnap J., Burkhard B., Lange O.L., 2001. Biological soil crusts: characteristics and distribution. In: J. Belnap, O.L. Lange (eds), 
Biological soil crusts: structure, function and management. Ecological Studies 150.

Berndtsson R., Nodomi K., Yasuda H., Persson T., Chen H., Jinno K., 1996. Soil water and temperature patterns in an arid desert dune sand. Journal of Hydrology 185: 221-240.

Bond R.D., Harris J.R., 1964. The influence of the microflora on the physical properties of sand. Effects associated with filamentous algae and fungi. Australian Journal of Soil Research 2: 111-122.

Brotherson J.D., Rushworth S.B., Johansen J.R., 1983. Influence of cryptogamic crusts on moisture relationship of soils in Navajo National Monument, Arizona. Great Basin Naturalist 43: 73-78.

Burcar S., Miller W.W., Tyler S.W., Johnson D.W., 1994. Seasonal preferential flow in two sierra Nevada soils. Soil Society American Journal 58: 1555-1561.

Burley J., 1990. The conservation and use of plant resources in dryland areas. In: A.S. Goudie (ed.), Techniques in Desert Reclamation. Wiley: 199-215.

Campbell S.E., 1979. Soil stabilization by prokaryotic crust. Implication for Precambrian land biota Origin of Life 9: 335-348.

Danin A., Bar-Or Y., Dor I., Yisraeli T., 1989. The role of cyanobacteria in stabilization of sand dunes in southern Israel. Ecologia Mediterranea 15: 55-64.

DeBano L.F., 2000. Water repellency in soils: a historical overview. Journal of Hydrology 231: 10-34.

Dekker L.W., Jungerius P.D., 1990. Water repellency in the dunes with special reference to the Netherland dunes of the European coast. Catena Suppl. 18: 173-183.

Dekker L.W., Ritsema C.J., 1994. How water moves in a water repellent soil. Potential and actual water repellency. Water Resources Research 30(9): 2507-2517.

Dekker L.W., Ritsema C.J., Wendorth O., Jarvis N., Oostindie K., Pohl W., Larson M., Gaudet J., 1999. Moisture distribution and wetting rates of soils at experimental fields in the Nethertlands, France, Sweden and Germany. Journal of Hydrology 215: 4-22.

Doerr D.H., 1998. On standardizing the "water drop penetration time" and the molarity of an ethanol droplet techniques to classify soil hydrophobicity: a case study using medium textural soils. Earth Surface Processes and Landforms 23: 663-668.

Doerr S.H., Shaksby R.A., Walsh R.P.D., 2000. Soil water repellency: its causes and hydro-geomorphological significance. Earth Surface Reviews 51: 33-65.

Eldridge D.E., 1993. Cryptogamic cover and soil surface conditions: Effects on hydrology on a semi-arid woodland soil. Arid Soil Research and Rehabilitation 7: 203-217.

Eldridge D.E., 2001. Biological soil crusts of Australia. In: J. Belnap, O.L. Lange (eds), Biological soil crusts: Structure, Function and Management. Ecological Studies 150: 119-132.

Eldridge D.E., Zaady E., Shachak M., 2000. Infiltration through three contrasting biological topsoil crusts in patterned landscapes in the Negev Desert, Israel. Catena 49: 323-336.

Hendricks J.M.H., Dekker L.W., Boersma O.H., 1993. Unstable wetting fronts in water-repellent field soils. Journal of Environmental Quality 22: 109-118.

Imeson A.C., Verstraten E.J., Van Muligen E.G., Sevink J., 1992. The effects of fire and water repellency on infiltration and runoff under Mediterranean type forest. Catena 17: 345-361.

Jungerius P.D., Dejong J.H., 1989. Variability of water repellence in the dunes along the Dutch coast. Catena 16: 491-497.

Kidron G.J., Yair A., 1997. Rainfall-runoff relationships over encrusted dunes surfaces, Nizzana, Western Negev, Israel. Earth Surface Processes and Landforms 22:169-1184.

Kidron G.J., Yair., A., Vonshak A., Abeliovich A., 2003. Microbiotic crust control of runoff generation in the Negev Desert. Water Resources Research 39(4): 1108.

Kidron G.J., 2015. The role of crust thickness in runoff generation from microbiotic crusts. Hydrological Processes 29: 17831792.
Krammes J.S., DeBano L.F., 1965. Soil wettability: a neglected factor in watershed management. Water Resources Research 1: 283-286.

Littmann T., Berkowicz S.M., 2008. The regional climating setting. In: S.W. Breckle, A. Yair, M. Veste (eds), Arid Dune Ecosystems. Ecological Studies 200: 49-63.

Mashum M., Farmer V.C., 1985. Origin and assessment of water repellency of a coastal South Australia soil. Australian Journal of Soil Research 23: 723-626.

Mazor G., Kidron G.J., Vonshak A., Abeliovitch A., 1996. The role of cyanobacterial exo-polysaccarides in structuring desert microbial crusts. FEMS Microbial Ecology 21: 121-130.

McCord J.T., Stephens D.D., 1987. Lateral moisture flow beneath a sandy hillslope without an apparent impeding layer. Hydrological Processes 1: 225-238.

Misak R.F., Draz M.Y., 1997. Sand drift control on selected coastal dunes and desert dunes in Egypt: case studies. Journal of Arid Environments 35: 17.28 .

Rietveld J., 1978. soil non-wettability and its relevance as a contributing factor to surface runoff on sandy on sandy soils in Mali. Report of the project: Production Primaire au Sahel, Wageningen.

Ritsema J.C., Dekker L.W., 1994. How water moves in a water repellent sandy soil: dynamics of finger flow. Water Resources Research 20: 2519-2531.

Ritsema J.C., Dekker L.W., 1997. Three-dimensional fingered flow patterns in a water repellent sandy field soil. Soil Science 162: 79-90.

Roberts F.G., Carson B.A., 1971. water repellence in sandy soils of Southern Australia. Australian Journal of Soil Science 58: $35-42$.

Rutin J., 1983. Erosional processes on a coastal sand dune, De blink, Noordwijkerhout. Physical Geography and Soil Laboratory Pub. 35. University of Amsterdam.

Savage S.M., Martin J.P., Letey J., 1969. Contribution of some soil fungi to natural and heat induced water repellency in sand. Soil Science Society America Proceedings 33: 405-409.

Stevens J.H., 1974. Sand stabilization in Saudi Arabia al-hasa oasis. Journal of Soil and Water Conservation 29: 33-129.

Tsoar H., Blumberg D.G., Wenkart R., 2008. Formation and Geomorphology of the North-Western Negev sand dunes. In: S.W. Breckle, A. Yair, M. Veste (eds), Arid Dune Ecosystems. Ecological Studies 200: 25-46.

Verrecchia E., Yair A., Kidron G.J., Verrecchia K., 1995. Physical properties of the psammophile cryptogamic crusts and their consequences on the water regime in sandy soils, north western Negev, Israel. Journal of Arid Environments 29: 427-437.

Waisel Y., 1960. Ecological studies on Tamarix Aphylla (L.) Karst. Plant and Soil 13(4): 356-364.

Wang Z., Wu O.J., Ritsema L.W., Dekker L.W., Feyen J., 2000. Effects of water repellency on infiltration rate and flow instability. Journal of Hydrology 231: 265-276.

Warren S.D., 2001. Biological soil crusts and hydrology in North American Deserts. In: J. Belnap, O.L. Lange (eds), Biological Soil Crusts: Structure, Function, and Management. Ecological Studies 150: 327-337.

Wessel A.T., 1998. On using the effective contact angle and the water penetration time for classification of water repellency in dune soils. Earth Processes and Landforms 13: 555-561.

Witter J.V., Jungerius P.D., Ten-Harkel M.J., 1991. Modeling water erosion and the impact of water repellency. Catena 18: 115124.

Yair A., 1983. Hillslope hydrology, water harvesting and areal distribution of some ancient agricultural systems in the Negev. Journal of Arid Environments 6: 283-301.

Yair A., 1990. Runoff generation in a sandy area. The Nizzana sands, Western Negev. Earth Surface Processes and Landforms 15: 597-607.

Yair A., 1994. The ambiguous impact of climate change at a desert fringe: Northern Negev,Israel. In: A.C. Millington, K. Pye 
(eds), Environmental change in drylands: biogeographical and geomorphological perspectives. Chichester: 199-227.

Yair A., 2001. Effects of biological soil crusts on water redistribution in the Northern Negev, Israel. A case study in longitudinal dunes. In: J. Belnap, O.L. Lange (eds), Biological Soil Crusts: Structure, Function and Management, Ecological Studies 150: 303-314.

Yair A., Almog R., Veste M., 2011. Differential hydrological response of biological topsoil crusts along a rainfall gradient in a sandy arid area: Northern Negev desert, Israel. Catena 87: 326-333.

Yair A., Lavee H., Greitser., 1997. Spatial and temporal variability of water percolation and movement in a system of longitudinal dunes, Western Negev. Hydrological Processes 11: 43-58.

Yang H., Liu L., Li X., Wei Y., Li X., Jia R., 2014. Water repellency of biological soil crusts and influencing factors on the southeast fringe of the Tengger Desert, North-Central China. Soil Science 179: 424-432. 